LAPORAN KASUS

\title{
Kematian Akibat Luka Tembak Sangat Dekat
}

\author{
Abdul Gafar Parinduri \\ Bagian Ilmu Forensik Fakultas Kedokteran Universitas Muhammadiyah Sumatera Utara \\ Email: sauqipancasilawati@gmail.com
}

\begin{abstract}
Abstrak: Saat ini korban karena kekerasan luka tembak, sangat sering didapati karena semakin banyak anggota masyarakat sipil memiliki senjata api, baik untuk pertahanan diri, maupun untuk tujuan lain. Pada prinsipnya pemeriksaan korban luka tembak, sama halnya dengan pemeriksaan luka pada trauma lain, namun ada satu yang spesifik yaitu dokter harus mengetahui dan memahami tentang senjata api, amunisi dan peluru ${ }^{(1)}$. Pada luka tembak terdapat dua jenis luka, diantaranya, luka tembak masuk dan luka tembak keluar. Luka tembak masuk terdiri dari: luka tembak tempel (contact wound), Luka tembak sangat dekat (close wound), luka tembak dekat (near wound), dan luka tembak jauh (distant wound $)^{(1,2)}$. Laporan kasus ini bertujuan untuk menentukan perihal penyebab kematian korban yang ditemukan melalui pemeriksaan forensik dan histopatologi, apakah korban meninggal karena bunuh diri, pembunuhan atau kecelakaan. Kasus terjadi di Serdang Bedagai, seorang perempuan umur 45 tahun, korban ditemukan meninggal di rumahnya. Pada pemeriksaan luar dan dalam dijumpai satu luka tembak masuk pada pipi sebelah kanan menembus rongga mulut, merobek pembuluh darah besar leher kanan, menembus paru-paru kanan bagian atas, menembus tulang iga 5 dan 6 kanan bagian belakang, proyektil berada di lapisan otot punggung kanan, dijumpai luka tembak masuk pada leher kanan, menembus kulit leher kanan (luka tembak keluar) dan dijumpai luka lecet dari leher kanan ke rahang kiri bawah (saluran anak peluru). Kesimpulan bahwa bahwa penyebab kematian korban adalah mati lemas akibat perdarahan yang banyak pada rongga dada oleh karena anak peluru (proyektil) yang menembus jaringan paru akibat luka tembak sangat dekat dan korban diduga dibunuh.
\end{abstract}

Kata kunci: Kekerasan, Luka Tembak, Pembunuhan

\section{The Death Caused By A Close Gunshot Wound}

Abstract: At present victims of violent gunshot wounds are very often found because more and more members of civil society have firearms, both for self defense, and for other purposes. In principle, the examination of victims of gunshot wounds, the same as examining wounds for other trauma, but there is one specific, namely, doctors must know and understand about firearms, ammunition and bullets ${ }^{(1)}$. In gunshot wounds there are several types of injuries, including,ngunshot wounds in and out gunshot wounds. Incoming gunshot wounds can be divided into: contact wound, contact wound very close (close wound), close wound (near wound), and gunshot woundfar (distant wound $)^{(1,2)}$. This case report aims to determine the cause of death of the victim found through forensic and histopathological examination, whether the victim died purely because of a gunshot wound suffered by the victim or other motives. The case that occurred in Serdang, a woman aged 45 years, the victim was found dead at his home. On examination the outside and inside found the wound gunshot entrance on the cheek next to the right to penetrate the cavity mouth, tearing vessels blood large right neck, penetrate the right lungs of passage above, penetrate five and six ribs bone rear right, the projectile is an a layer of right back muscle, encountered entrance gunshot wound on the right neck, pierce the skin of the right neck ( shoot out wound) and found the blisters wound on the right neck to the bottom left jaw ( child bullet track). The cause of death of the victim was 
suffocation due to profuse bleeding in the chest cavity due to a bullet (projectile) penetrating the lung tissue due to a very close gunshot wound. The victim was allegedly killed.

Keywords: Violence, Gunshot Wounds, Murder

\section{PENDAHULUAN}

Saat ini kekerasan luka tembak, sangat sering didapati karena semakin banyak masyarakat sipil yang memiliki senjata api, baik untuk pertahanan diri, maupun untuk tujuan lain. Pada prinsipnya pemeriksaan korban luka tembak, sama halnya dengan pemeriksaan luka pada trauma lain, namun ada satu yang spesifik yaitu, dokter harus mengetahui dan memahami tentang senjata api, amunisi dan peluru. Tanpa memahami ini, akan sulit memberikan bantuan yang adekuat, karena perlukaan pada tubuh akhirnya berdasarkan ketiga unsur tersebut ${ }^{(1,2)}$. Pengetahuan yang baik tentang berbagai luka akibat senjata api memerlukan perhatian yang serius bagi seorang dokter sebagai pemeriksa termasuk tentang senjata api secara mendasar, jalannya anak peluru, pelatuk, jarak dan proses perjalanan anak peluru di dalam tubuh dan sebagainya $^{(2)}$.

Luka tembak adalah luka yang disebabkan adanya penetrasi anak peluru dengan tubuh ${ }^{(1)}$. Jika anak peluru mengenai tubuh, maka kelainan yang terjadi merupakan resultante dari banyak faktor. Pada bagian tubuh tempat masuknya anak peluru, bagian tubuh sebelah dalam dan bagian tubuh tempat keluarnya anak peluru bentuk kelainannya tidak sama, karena faktor-faktor yang mempengaruhinya berbeda-beda. Pada kasus luka tembak, perlu sekali diperhatikan:Luka Tembak Masuk (LTM) danLuka Tembak Keluar (LTK) $)^{(4,8)}$

\section{Luka Tembak Masuk}

Pada saat seseorang melepaskan tembakan dan kebetulan mengenai sasaran yaitu tubuh korban, maka pada tubuh korban tersebut akan akan didapatkan perubahan yang diakibatkan oleh berbagai unsur atau komponen yang keluar dari laras senjata api tersebut. Berdasarkan jarak tembakan, luka tembak masuk dapat dibedakan atas:

1. Luka Tembak Tempel (Contact Wound) Terjadi bila laras senjata menempel pada kulit. Luka tembak masuk biasanya berbentuk bintang (stellate/cruciform) karena tekanan gas yang tinggi waktu mencari jalan keluar akan merobek jaringan. Tampak nyata terutama bila di bawah kulit terdapat tulang. Pada luka didapati jejas laras (memar) bekas ujung laras yang ditempelkan pada kulit, berbentuk sirkuler akibat hentakan balik dari ujung laras senjata. Gas dan mesiu yang tidak terbakar didapati dalam jaringan luka (tato). Didapati kadar CO yang tinggi, berupa jelaga dalam jaringan luka. Luka tembak tempel 
biasanya didapati pada kasus bunuh diri. Oleh karena itu sering didapati adanya kejang mayat (cadaveric spasme). Luka tembak tempel sering didapati di pelipis, dahi atau dalam mulut. Pada umumnya luka tembak masuk kontak adalah merupakan perbuatan bunuh $\operatorname{diri}^{(2,6,7)}$.

2. Luka Tembak Sangat Dekat (Close Wound)

Luka tembak masuk jarak sangat dekat (close wound) sering disebabkan pembunuhan. Dengan jarak sangat dekat $( \pm 15 \mathrm{~cm})$, maka akan didapati cincin memar, tanda-tanda luka bakar, jelaga dan tattoo disekitar lubang masuk. Pada daerah sasaran tembak didapati luka bakar karena semburan api dan gas panas, kelim jelaga (arang), kelim tato akibat mesiu yang tidak terbakar dan luka tembus dengan cincin memar di pinggir luka ${ }^{(2,6,7)}$.

3. Luka Tembak Dekat (Near Wound)

Luka dengan jarak di bawah $70 \mathrm{~cm}$ (sekitar 2 kaki) akan lubang luka, cincin memar dan tattoo di sekitar luka masuk. Biasanya karena pembunuhan. Pada luka tembak penting sekali memeriksa baju korban. Harus dicocokkan apakah lobang di tubuh korban setentang dengan lobang di pakaian ${ }^{(2,6,7)}$.

4. Luka Tembak Jauh (Distant Wound)

Disini tidak ada kelim tatto, hanya ada luka tembus oleh peluru dan cincin memar. Terkadang diameter cincin sedikit lebih kecil dari anak peluru. Jarak penembakan sulit atau hampir tak mungkin ditentukan secara pasti. Tembakan dari jarak lebih dari $70 \mathrm{~cm}$ dianggap sebagai tembakan jarak jauh, karena partikel mesiu biasanya tidak mencapai sasaran lagi ${ }^{(2,6,7)}$. Tidak ada bubuk mesiu maupun gas yang bisa terbawa hingga jarak jauh. Hanya anak peluru yang dapat terlontar memebihi beberapa kaki. Sehingga luka yang ada disebabkan oleh anak peluru saja.

Terdapat beberapa karakteristik luka yang dapat dinilai. Umumnya luka berbentuk sirkular atau mendekati sirkular. Tepi luka compang-camping. Jika anak peluru berjalan dengan gaya non-perpendikular maka tepi compang-camping tersebut akan melebar pada salah satu sisi. Pemeriksaan ini berguna untuk menentukan arah anak peluru ${ }^{(4,5)}$.

Pada luka tembak masuk jarak jauh memberi arti yang besar terhadap pengusutan perkara. Hal ini karena luka jenis ini menyingkirkan kemungkinan penembakan terhadap diri sendiri, baik sengaja atau tidak.

Terdapat 4 pengecualian, yaitu (1) Senjata telah di atur sedemikian rupa sehingga dapat di tembakkan sendiri oleh korban dari jarak jauh; (2) kesalahan hasil pemeriksaan karena bentuk luka tembak tempel yang mirip luka tembak jarak jauh; (3) Kesulitan interpretasi karena adanya pakaian yang menghalangi jelaga atau bubuk mesiu mencapai kulit; (4) Jelaga atau bubuk mesiu telah tersingkir. 
Hal tersebut terjadi bila tidak ada pengetahuan pemeriksa dan dapat berakibat serius terhadap penyelidikan.

Luka-luka yang muncul pada tempat ini (Luka Tembak Masuk), disebabkan oleh faktorfaktor seperti :

- Gaya kinetik anak peluru (proyektil).

$>$ Suhu panas anak peluru (proyektil).

$>$ Semburan api.

> Ledakan gas dari mesiu (pada kasus trauma tembak tempel).

Percikan mesiu yang tidak terbakar.

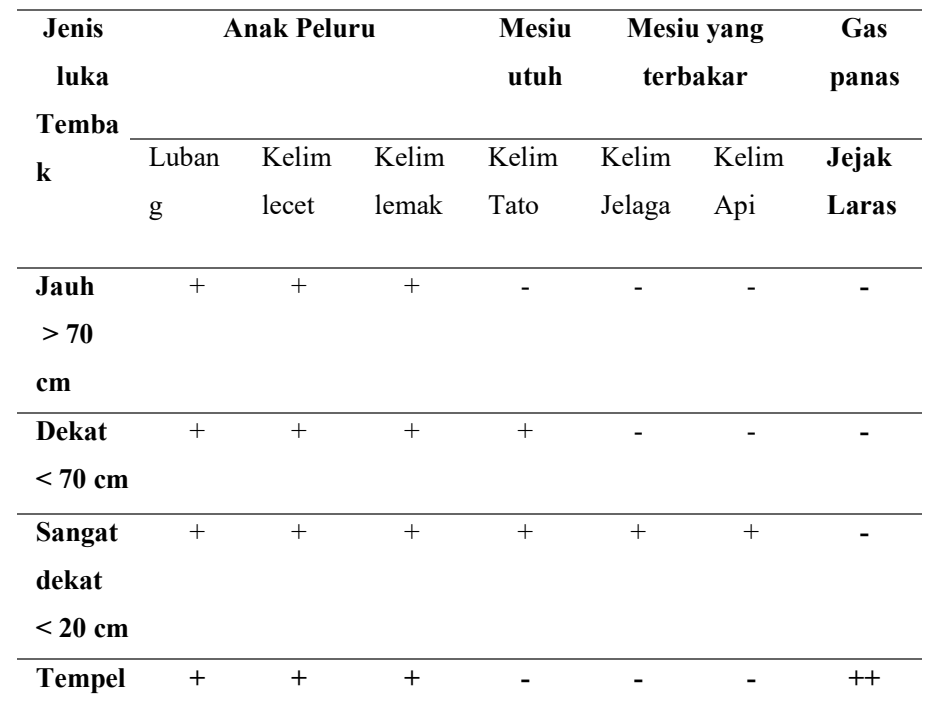

Saluran Luka Tembak/Saluran Anak Peluru adalah bila peluru di dalam tubuh tidak terbentur dengan organ yang keras (tulang) maka saluran luka tembak masuk dan luka tembak keluar akan lurus. Tetapi bila berbenturan dengan organ yang keras seperti tulang maka saluran anak peluru dapat berbelok $^{(1,4)}$.

\section{b. Luka Tembak Keluar}

Luka tembak keluar ini ialah setelah peluru membuat luka tembak masuk dan saluran luka tembakan maka akhirnya peluru akan mengenai kulit lagi dari sebelah dalam dan kulit terdorong ke luar. Kalau batas kekenyalan kulit dilampaui, maka kulit dari dalam menjadi robek dan akhirnya timbul suatu lubang luka baru, dan luka baru inilah yang dinamakan luka tembak keluar.

Jika sebuah peluru setelah membuat lubang luka tembakan masuk dan mengenai tulang (benda keras), maka bentuk dari pada peluru tadi menjadi berubah. Tulang-tulang yang kena peluru tadi akan menjadi patah pecah atau kadang-kadang remuk. Akibatnya waktu peluru menembus terus dan membuat lubang luka tembak keluar, tidak hanya peluru yang berubah bentuknya, tapi juga diikuti oleh pecahan-pecahan tulang tadi oleh karena ikut terlempar karena dorongan dari peluru.

Tulang-tulang inipun kadang-kadang mempunyai kekuatan menembus juga. Kejadian inilah yang mengakibatkan luka tembakan keluar yang besar dan lebar, sedangkan bentuknya tidak tertentu. Sering kali besar luka tembak keluar berlipat ganda dari pada besarnya luka tembakan masuk. Misalnya saja luka tembakan masuk beserta 
contusio ring sebesar kira-kira $8 \mathrm{~mm}$ dan luka tembakan keluar sebesar uang logam (seringgit).

Berdasarkan ukurannya maka ada beberapa kemungkinan yaitu, bila luka tembak keluar ukurannya lebih besar dari luka tembak masuk, maka biasanya sebelum keluar anak peluru telah mengenai tulang hingga berpecahan dan beberapa serpihannya ikut keluar. Serpihan tulang ini bisa menjadi peluru baru yang membuat luka keluar menjadi lebih lebar. Bila luka tembak keluar ukurannya sama dengan luka tembak masuk, maka hal ini didapatkan bila anak peluru hanya mengenai jaringan lunak tubuh dan daya tembus waktu keluar dari kulit masih cukup besar. Luka yang terjadi dapat disebabkan oleh faktor-faktor sebagai berikut:

> Gaya kinetik anak peluru.

Perubahan bentuk dan arah anak peluru, sesudah membentur bagian keras tubuh (tulang).

Serpihan tulang yang kemudian dapat berfungsi sebagai anak peluru sekunder (secondary missiles).

Bila tidak ditemukan cincin memar disekitar lubang luka, maka ini merupakan patokan sebagai luka keluar. Pada luka keluar bisa didapati jaringan lemak menghadap keluar, walaupun kadang-kadang sulit memastikannya. Bentuk dan besar luka keluar beragam, tergantung posisi peluru keluar dan kecepatan menembus kulit. Lebih mudah memastikan bila didapati serpihan tulang, apalagi bila dibantu foto rontgen ${ }^{(2,3,5)}$.

Ada 3 kemungkinan yang terjadi besarnya luka tembak keluar (LTK) adalah :

1) Luka tembak masuk lebih kecil dari tembak keluar

Adapun faktor-faktor yang menyebabkan LTK lebih besar dari LTM adalah perubahan luas peluru, oleh karena terjadi deformitas sewaktu peluru berada dalam tubuh dan membentur tulang, peluru sewaktu berada dalam tubuh mengalami perubahan gerak, misalnya karena terbentur bagian tubuh yang keras peluru bergerak berputar dari ujungujung (end to end) keadaan ini disebut "tumbling “. Pergerakan peluru yang lurus, menjadi tidak beraturan ini disebut "yawing". Peluru pecah menjadi beberap fragmen, fragmen-fragmen ini akan menyebabkan bertambah besarnya LTK, bila peluru mengenai tulang dan fragmen tulang tersebut turut terbawa keluar, maka fragmen tulang tersebut akan membuat robekan tambahan, sehingga akan memperbesar luka tembak keluarnya.

2) Luka tembak masuk sama dengan luka tembak keluar

Hal ini terjadi kalau anak peluru mengenai bagian yang lunak dari tubuh dan daya tembus 
anak peluru hampir sama dengan waktu keluarnya.

3) Luka tembak masuk lebih besar dari luka tembak keluar ${ }^{(5)}$.

Dapat disebabkan kecepatan atau velocity peluru sewaktu akan menembus keluar berkurang, sehingga kerusakannya (lubang luka tembak keluar) akan lebih kecil perlu diketahui bahwa kemampuan peluru untuk dapat menimbulkan kerusakan berhubungan langsung dengan ukuran peluru dan velocitasnya yaitu, adanya benda yang menahan atau menekan kulit pada daerah dimana peluru akan keluar, yang berarti menghambat kecepatan peluru, luka tembak keluar akan lebih kecil bila dibandingkan dengan luka tembak masuk.

Perbedaan luka tembak masuk dan luka tembak keluar

\begin{tabular}{ll}
\hline \multicolumn{1}{c}{ Luka tembak masuk } & \multicolumn{1}{c}{ Luka tembak keluar } \\
\hline Ukurannya lebih kecil karena & Ukurannya lebih besar dan \\
peluru menembus kulit seperti & lebih tidak teratur \\
bor dengan kecepatan tinggi. & dibandingkan luka tembak \\
& masuk. \\
\hline Pinggiran luka melekuk kearah & Pinggiran luka melekuk \\
dalam karena peluru menembus & keluar karena peluru \\
kulit dari luar. & menuju keluar. \\
\hline Pinggiran luka megalami abrasi. & Pinggiran luka tidak \\
\hline Bisa tampak kelim lemak. & mengalami abrasi. \\
\hline Pakaian masuk kedalam luka. & Tidak terdapat kelim \\
\hline Pada luka bisa tampak terbakar, & Tidak ada. \\
\hline kelim tato atau jelaga. & lemak. \\
\hline Bisa tampak kelim lemak. & Tampak seperti gambaran \\
\hline & mirip \\
\hline & \\
\hline
\end{tabular}

\begin{tabular}{ll}
\hline & kerucut. \\
\hline $\begin{array}{l}\text { Bisa tampak warna merah akibat } \\
\text { adanya zat CO. }\end{array}$ & Tidak ada. \\
\hline $\begin{array}{l}\text { Disekitar luka tampak kelim } \\
\text { ekimosis. }\end{array}$ & Tidak ada. \\
\hline Perdarahannya lebih sedikit. & Tidak ada. \\
\hline $\begin{array}{l}\text { Pemeriksaan radiology atau } \\
\text { analisa aktivitas netron } \\
\text { mengungkapkan adanya } \\
\text { lingkaran timah atau zat besi } \\
\text { disekitar luka. }{ }^{(3)}\end{array}$ \\
\hline
\end{tabular}

\section{LAPORAN KASUS}

Kasus yang terjadi di Serdang Bedagai pada tanggal 06 oktober 2019 pukul 07:30 WIB korban adalah perempuan umur 45 tahun, korban ditemukan meninggal di rumahnya dan berlumuran darah.

\section{PEMERIKSAAN LUAR:}

1. Pada pipi kanan, dijumpai luka berbentuk bulat, diameter $1 \mathrm{~cm}$, dengan jarak $1 \mathrm{~cm}$ dari garis tengah tubuh dan $10 \mathrm{~cm}$ dari telinga, dengan ciri luka: arah jaringan kedalam, dijumpai luka lecet, tepi luka berwarna hitam.

2. Pada rahang bawah dijumpai luka lecet sampai ke leher.

3. Pada leher leher sebelah kanan, dijumpai luka berbentuk bulat diameter $1 \mathrm{~cm}$, dengan jarak $10 \mathrm{~cm}$ dari garis tengah tubuh dan $5 \mathrm{~cm}$ dari 
puncak bahu, dengan ciri luka arah jaringan kedalam, pinggir tidak rata, sekitar luka dijumpai berwarna hitam.

4. Dijumpai luka berbentuk bulat diameter $1 \mathrm{~cm}$ dengan jarak $10 \mathrm{~cm}$ dari garis tengah tubuh dan $15 \mathrm{~cm}$ dari puncak bahu, ciri luka pinggir tidak rata, arah jaringan keluar.

5. Pada punggung sebelah kanan dijumpai luka memar, teraba keras.

\section{PEMERIKSAAN DALAM:}

1. Dijumpai resapan darah pada kulit leher sebelah kanan.

2. Dijumpai resapan darah pada pembuluh darah besar leher sebelah kiri dan luka robek pada pembuluh darah besar leher sebelah kanan.

3. Pada pembukaan saluran napas atas dijumpai buih halus yang sukar pecah bercampur darah.

4. Dijumpai darah pada rongga dada kanan $1150 \mathrm{ml}$ dan rongga dada kiri $240 \mathrm{ml}$.

5. Dijumpai resapan darah pada kulit dada bagian dalam sebelah kanan.

6. Dijumpai luka robek pada jaringan paru kanan bagian atas sebelah luar dan dalam dengan ukuran panjang $3 \mathrm{~cm}$, lebar $2 \mathrm{~cm}$.

7. Pada pemotongan paru dijumpai buih halus bercampur darah.

8. Pada pembukaan kulit pungung sebelah kanan, dijumpai resapan darah pada kulit punggung bagian dalam ukuran panjang 3 $\mathrm{cm}$ lebar $2 \mathrm{~cm}$ jarak dari garis tengah tubuh $23 \mathrm{~cm}$ dan $4 \mathrm{~cm}$ dari ketiak kanan, dijumpai proyektil (anak peluru) berwarna perak, diameter $1 \mathrm{~cm}$ panjang $2,5 \mathrm{~cm}$.

9. Dijumpai patah tulang iga 5 dan 6 kanan bagian belakang.

\section{PEMERIKSAAN HISTOPATOLOGI \\ Makroskopis:}

Diterima 4 buah wadah berupa :

- Kulit (luka masuk satu), diterima sepotong jaringan berwarna coklat keabuan dengan permukaan tidak rata, konsistensi kenyal, berat dua gram, ukuran $0,7 \mathrm{~cm}$ kali $0,2 \mathrm{~cm}$ kali $0,1 \mathrm{~cm}$.

- Kulit (luka masuk dua), diterima sepotong jaringan berwarna coklat keabuan dengan permukaan tidak rata, konsistensi kenyal, berat $2 \mathrm{gr}$, ukuran $1,2 \mathrm{~cm}$ kali $0,5 \mathrm{~cm}$ kali 0,2 $\mathrm{cm}$. Kulit beserta rambut (luka keluar satu), diterima sepotong jaringan berwarna coklat keabuan dengan permukaan tidak rata, konsistensi kenyal, berat 2 gr, ukuran 1,4 cm kali 0,4 cm kali 0,2 cm Kulit (luka keluar dua), diterima sepotong jaringan berwarna coklat keabuan dengan permukaan tidak rata, konsistensi kenyal, berat 2 gr, ukuran $1,3 \mathrm{~cm}$ kali $0,7 \mathrm{~cm}$ kali $0,1 \mathrm{~cm}$.

\section{Mikroskopis:}

- Sediaan jaringan dari kulit atau luka tembak masuk satu dan dua, menunjukkan 
gambaran yang hampir sama. Jaringan terdiri dari lapisan epitel tatah berlapis yang mengalami destruksi dengan morfologi inti dalam batas normal. Tidak dijumpai residual carbon. Stroma terdiri dari jaringan ikat fibrous. Pembuluh darah dalam batas normal.

- Sediaan jaringan dari kulit dan otot (luka tembak keluar satu dan dua), pada luka keluar satu menunjukkan gambaran tampak lapisan kulit dengan pelapis epitel tatah berlapis dengan morfologi inti dalam batas normal. Pada lapisan epidermis dijumpai area destruksi, tidak dijumpai residual carbon. Pada luka keluar dua, tampak serabut otot dengan morfologi inti dalam batas normal diantaranya tampak jaringan ikat fibrokolagen.

Kesimpulan: menyokong suatu luka tembak masuk dan keluar

\section{PEMBAHASAN}

Pemeriksaan Luar:

1. Pada pipi kanan, dijumpai luka berbentuk bulat, diameter $1 \mathrm{~cm}$, dengan jarak $1 \mathrm{~cm}$ dari garis tengah tubuh dan $10 \mathrm{~cm}$ dari telinga, arah jaringan kedalam, dijumpai luka lecet, tepi luka berwarna hitam. Ini menunjukkan bahwa luka tersebut merupakan luka tembak masuk dengan jarak sangat dekat.
2. Pada rahang bawah dijumpai luka lecet sampai ke leher yang menunjukkan bahwa luka tersebut merupakan saluran anak peluru dari luka tembak masuk pada leher sebelah kanan.

3. Pada leher sebelah kanan, dijumpai luka berbentuk bulat diameter $1 \mathrm{~cm}$, dengan jarak $10 \mathrm{~cm}$ dari garis tengah tubuh dan 5 cm dari puncak bahu, dengan ciri luka arah jaringan kedalam, pinggir tidak rata, tepi luka berwarna hitam. Ini menunjukkan bahwa luka tersebut merupakan luka tembak masuk kedua.

4. Dijumpai luka berbentuk bulat diameter 1 $\mathrm{cm}$ dengan jarak $10 \mathrm{~cm}$ dari garis tengah tubuh dan $15 \mathrm{~cm}$ dari puncak bahu, ciri luka pinggir tidak rata, arah jaringan keluar. Ini menunjukkan bahwa luka tersebut merupakan luka tembak keluar.

5. Pada punggung sebelah kanan dijumpai luka memar, teraba keras yang merupakan tanda-tanda adanya peluru dibawah kulit.

Pemeriksaan Dalam:

1. Dijumpai resapan darah pada kulit leher sebelah kanan, pembuluh darah besar leher sebelah kiri dan luka robek pada pembuluh darah besar leher sebelah kanan yang menunjukkan saluran anak peluru pada luka tembak masuk kedua.

2. Pada pembukaan saluran napas atas dijumpai buih halus yang sukar pecah 
bercampur darah. Hal ini menunjukkan korban mengalami asfiksia (mati lemas).

3. Dijumpai resapan darah pada kulit dada bagian dalam sebelah kanan yang menunjukkan saluran anak peluru pada luka tembak masuk kedua.

4. Dijumpai luka robek pada jaringan paru kanan bagian atas sebelah luar dan dalam dengan ukuran panjang $3 \mathrm{~cm}$, lebar $2 \mathrm{~cm}$. Robekan tersebut oleh karena anak peluru.

5. Dijumpai darah pada rongga dada kanan $1150 \mathrm{ml}$ dan rongga dada kiri $240 \mathrm{ml}$ yang berasal dari robekan jaringan paru yang robek oleh karena anak peluru.

6. Pada pemotongan paru dijumpai buih halus bercampur darah. Hal ini menunjukkan korban mengalami asfiksia (mati lemas).

7. Pada pembukaan kulit pungung sebelah kanan, dijumpai resapan darah pada kulit punggung bagian dalam ukuran panjang 3 $\mathrm{cm}$ lebar $2 \mathrm{~cm}$ jarak dari garis tengah tubuh $23 \mathrm{~cm}$ dan $4 \mathrm{~cm}$ dari ketiak kanan, dijumpai proyektil (anak peluru) berwarna perak, diameter $1 \mathrm{~cm}$ panjang $2,5 \mathrm{~cm}$ yang merupakan anak peluru dari luka tembak masuk kedua.

8. Dijumpai patah tulang iga 5 dan 6 kanan bagian belakang yang menunjukkan bahwa anak peluru mengenai tulang iga kanan bagian belakang.
Sesuai dengan temuan yang didapatkan dari hasil pemeriksaan forensik dan histopatologi pada korban perempuan umur 45 tahun. Dari hasil pemeriksaan luar dan dalam pada jenazah, dapat disimpulkan bahwa penyebab kematian korban mati lemas akibat perdarahan yang banyak pada rongga dada oleh karena anak peluru (proyektil) yang menembus jaringan paru akibat luka tembak sangat dekat. Korban diduga dibunuh.

\section{DAFTAR PUSTAKA}

1) Dahlan S, Ilmu Kedokteran Forensik Pedoman bagi Dokter dan Penegak Hukum, Cetakan Ke 3, Universitas Diponegoro Semarang 2000, Hal 93-106.

2) Amir Amri, Rangkaian Ilmu Kedokteran Forensik, Fakultas Kedokteran Universitas Sumatera Utara, Medan, Edisi ke II cetakan ke 3, Tahun 2007, Hal 91-103.

3) Gani MH. Ilmu Kedokteran Forensik, Bagian Kedokteran Forensik. Fakultas kedokteran Universitas Andalas, Padang 2002 .Hal 50-54.

4) Ilmu Kedokteran Forensik. Bagian Kedokteran Forensik, Fakultas Kedokteran Universitas Indonesia, Jakarta, 1997. Hal. 44-80.

5) Bernard Knight, Forensik Pathologi, second edition, Arnold, New York 1996, Hal 243-73.

\section{KESIMPULAN}


6) Nandy A.Principles of Forensic Medicine.

New central book agency (p) ltd.

Calcuta.India: 1996: Hal 240-65.

7) Hamdani N. Ilmu Kedokteran Kehakiman, Edisi II, PT. Gramedia, Jakarta, 1992. Hal.109-16.

8) Idries Munim Abdul, Pedoman Ilmu Kedokteran Forensik, Edisi Pertama, Jakarta, 1997. Hal. 44-80.

9) Chada PV. Catatan Kuliah Ilmu Forensik dan Toksikologi, Edisi V, ahli bahasa J. Hutauruk, Widya Medika, Jakarta, 1995. Hal 76-83.

10) Wahid, S.A. Patologi Forensik. Kematian akibat luka tembak. Dewan Bahasa dan Pustaka Kementerian Pendidikan Malaysia, Kuala Lumpur, 1973. Hal. 192228 